\title{
PRESSURE SORES AMONG MALNOURISHED NECROPSIED ADULTS - PRELIMINARY DATA
}

Daniel Ferreira da Cunha, Ricardo Boggio Frota, Maysa Silva Arruda, Selma Freire de Carvalho da Cunha and Vicente de Paula Antunes Teixeira

RHCFAP/3007

CUNHA DF da et al. - Pressure sores among malnourished necropsied adults - preliminary data.

Rev. Hosp. Clín. Fac. Med. S. Paulo 55 (3): 79-82, 2000.

SUMMARY : Pressure sores are common among bedridden, elderly, or malnourished patients, and may occur in terminal ill patients because of impaired mobility, fecal or urinary incontinence, and decreased healing capacity. The aim of this study was to compare frequency of pressure sores between malnourished and non-malnourished necropsied adults.

Method: All ( $\mathrm{n}=201)$ adults (age $\geq 18$ years) autopsied between 1986 and 1996 at the Teaching Hospital of Triangulo Mineiro Medical School (Uberaba) were eligible for the study. Gender, race, weight, height and main diagnoses were recorded. Ninety-six cases were excluded because of probable body water retention (congestive heart failure, hepatic insufficiency, nephrotic syndrome) or pressure sores secondary to peripheral vascular ischemia. Body mass index (BMI) was used to define malnourished (BMI $<18.5$ $\mathrm{kg} / \mathrm{m}^{2}$ ) and non-malnourished (BMI $>18.5 \mathrm{~kg} / \mathrm{m}^{2}$ ) groups.

Results: Except for weight (42.5kg; range: $28-57$ vs. 60; 36-134.5kg) and BMI (16.9; range: 12.4-18.5 vs. 22.7; range: 18.5$\left.54.6 \mathrm{~kg} / \mathrm{m}^{2}\right)$, respectively, there were no statistical differences among 43 malnourished and 62 non-malnourished cases in relation to age $(54.9 \pm 20.4$ vs. $52.9 \pm 17.9$ years), percentage of white persons $(74.4$ vs. $64.5 \%)$, male gender $(76.7$ vs. $69.3 \%)$ and main diagnoses. Five malnourished $(11.6 \%)$ and 7 (11.5\%) non-malnourished cases had pressure sores $(\mathrm{p}=0.89)$.

Conclusion: Pressure sores were equally common findings in necropsied persons with protein-energy malnutrition, as assessed by body mass index.

DESCRIPTORS: Pressure sores. Protein-energy malnutrition. Necropsy. Terminal patients. Acute phase response.

Pressure sores (PS) are ulcerations of the skin at sites of bony protuberances, and are thought to be slothful chronic wounds forming slowly because of poor nursing ${ }^{3}$. However, despite frequently affecting older persons confined to bed for long periods of time $^{11}$, PS are also observed in critically ill patients because of impaired mobility and acute tissue compression with subsequent reduced blood flow to the ischemic area, which causes dermal hypoxia, necrosis, skin breakdown, and eventually bacterial contamination ${ }^{9,13,15}$.

PS risk factors include skin fragility, fecal and/or urinary incontinence, moisture, and decreased mental status ${ }^{1,9}$. Signs and symptoms of malnu- trition are also often observed in patients with $\mathrm{PS}^{5,10,11,1}$, and include decreased body weight ${ }^{2,18}$, low triceps skinfold $^{5}$, hypoalbuminemia ${ }^{16}$ and lymphopenia $^{2}$.

Because the end of life is often associated with relative immobility, PS would be common in terminal patients. In addition, as loss of ability to eat and drink are preterminal or terminal events among dying patients ${ }^{14}$, our aim was to compare pressure sores frequency in necropsied adults with or without malnutrition.

From the Department of Pathology and Nutrology, Faculty of Medicine, Triangulo Mineiro Medical School.

\section{METHOD}

This retrospective study was conducted at a 400-bed University Hospital of Triângulo Mineiro Medical School, Uberaba, Brazil, after official approbation by the institutional Ethics Committee board. All adults (age $\geq 18$ years) autopsied between 1986 and 1996 with complete records, including data about gender, race, weight and height $(\mathrm{n}=201)$, were initially eligible for the study.

Because of possible abnormal water retention that could affect body weight and body mass index, 94 (46.8\%) persons with ascites, edema, and signs of congestive heart failure 
(cardiomegaly associated with generalized edema, ascites, pleural effusion, and hepatomegaly), chronic liver diseases (jaundice plus viral or alcoholic hepatitis or cirrhosis), or nephrotic syndrome due to glomerular disease, were excluded. Another exclusion criteria were chronic venous stasis or ischemic ulcers of the extremities.

Nutritional status was assessed by the body mass index (BMI), based on both body weight and height registered at necropsy $\left(\mathrm{BMI}=\mathrm{wt}(\mathrm{kg}) / \mathrm{ht}^{2}\left(\mathrm{~m}^{2}\right)\right.$. The malnourished group consisted of individuals with BMI $<18.5 \mathrm{~kg} / \mathrm{m}^{2}$; and individuals with BMI $\geq 18.5 \mathrm{~kg} / \mathrm{m}^{2}$ comprised the non-malnourished group $^{12}$.

Acute phase response syndrome, a condition associated with positive body water balance trend, was defined by death associated with severe infection (purulent peritonitis, bilateral pneumonia, acute pancreatitis, bacterial meningitis, acute bacterial endocarditis, acute bilateral pyelonephritis, pulmonary or disseminated tuberculosis), or massive brain or mesenteric infarction, plus gastric stress ulcers and/or spleen reactional state ${ }^{6}$. Stress ulcers were defined as the presence of ulcerative, superficial, necrotic or necro-hemorrhagic ulcers, often multiple, located in the gastric or duodenal mucosa. Spleen reactional lymphoid hyperplasia was registered when there was spleen enlargement caused by acute congestion of the red pulp, sometimes associated with infiltrate of neutrophils, plasma cells or eosinophils throughout the white and red pulps.

PS were staged according to Shea ${ }^{17}$. Presence of aseptic or purulent stage II (shallow ulcer penetrating to junction with subcutaneous fat), stage III (extending into subcutaneous fat), or stage IV (extending beyond subcutaneous fat to bone) were recorded. Irregular erythematous skin area was not considered stage I PS, due to possible confusion with corpse livor mortis.
Mann-Whitney test was applied to compare non-homogeneous numeric data (age, weight and BMI), that were expressed as median and minimum and maximum values (range). The chisquare or Fisher's exact tests were used to compare frequencies. Probabilities (p) less than 0.05 were considered significant.

\section{RESULTS}

A total of 105 cases without edema or clear-cut signs of water retention were studied; 43 cases $(41 \%)$ were classified as malnourished. There were no statistical differences among malnourished and non-malnourished individuals, respectively, in relation to age $(54.9 \pm 20.4$ vs. $52.9 \pm 17.9$ years $)$, predominance of white persons $(74.4$ vs. $64.5 \%$ ), or male gender (76.7 vs. $69.3 \%$ ).

Except for anthropometric data, there were no statistical differences between malnourished and non-malnourished groups, respectively, in relation to the diagnoses of infections $(62.8 \%$ vs. $51.6 \%$ ), malignant neoplasms (20.9\% vs. $14.0 \%)$, spleen reactional state $(37.2 \%$ vs. $24.2 \%)$, stroke $(9.3 \%$ vs. $20.9 \%$ ), AIDS (9.3\% vs. $8.0 \%)$, acute or chronic pancreatitis $(11.6 \%$ vs. $12.9 \%)$, or hepatic steatosis $(27.9 \%$ vs. $16.1 \%)$. Sixty (57.1\%) individuals fulfilled the criteria for acute phase response syndrome, which was similarly distributed among malnourished
(55.8\%) and non-malnourished individuals $(58.1 \%)$. Elderly persons (age $\geq 65$ years) were similarly seen in both groups: $27.9 \%$ among malnourished and $30.6 \%$ in non-malnourished.

Five malnourished $(11.6 \%)$ and seven non-malnourished $(11.5 \%)$ cases had PS $(\mathrm{p}=0.59)$. Most recorded PS was classified as Shea class II or III, and most individuals $(66.7 \%)$ had a single decubitus ulcer; the coccyx, the ischia, and the heels were the most commonly ulcerated sites. Concerning the ratio of PS number/patient, there was no statistical difference between malnourished ( $n=1$; range $1-7)$ and non-malnourished cases $(n=2$; range 1 4); results for purulent PS were similar (malnourished: 3 of 5 cases; nonmalnourished: 2 of 7 cases; $\mathrm{p}=0.31$ ).

\section{DISCUSSION}

This study has described the high prevalence (43 of 105 cases) of malnutrition among adults necropsied at our University Hospital, in addition to similar percentage of advanced grade pressure sores in malnourished $(11.6 \%)$ and non-malnourished $(11.5 \%)$ cases. Likewise, the number of PS per patient was not different between malnourished and non-malnourished groups. These findings cannot be ascribed to differences in demographic characteristics, to acute phase response syndrome presence, or to associated diagnoses. Indeed, results indicate that

Table 1 - Clinical features, demographic and anthropometric data and frequency of pressure sores in malnourished or non-malnourished autopsied adults.

\begin{tabular}{lcc}
\hline Parameters & Malnourished $(\mathrm{n}=43)$ & Non-malnourished $(\mathrm{n}=62)$ \\
\hline Age (years) & $58(18-112)$ & $51(21-92)$ \\
White persons $(\%)$, & 74.4 & 64.5 \\
Gender, male $(\%)$ & 76.7 & 69.3 \\
Weight $(\mathrm{kg}) *$ & $42.5(28-57)$ & $60(36-134.5)$ \\
Body mass index $\left(\mathrm{kg} / \mathrm{m}^{2}\right)^{*}$ & $16.88(12.41-18.47)$ & $22.66(18.5-54.57)$ \\
Acute phase response syndrome $(\%)$ & 55.8 & 58.1 \\
Pressure sores $(\%)$ & 11.6 & 11.5 \\
$* \mathrm{p}<0.01$ & &
\end{tabular}

$* \mathrm{p}<0.01$ 
despite being common among necropsied persons, PS presence is not always associated with low body weight or decreased body mass index.

PS prevalence varies from $3 \%$ to $11 \%$ among patients hospitalized in general wards ${ }^{2}$, and PS presence adds significantly to hospital length-of-stay, morbidity, and mortality ${ }^{9}$. The only paper referring to PS prevalence among the deceased adult population found a general frequency of $23.6 \%{ }^{8}$; however, the accuracy of these figures was probably limited by the ability of the funeral home workers to perform an adequate dermal examination.

Data about the relationship between malnutrition and pressure sores are incomplete and contradictory ${ }^{10}$. However, a well-conducted study suggests that patients with pressure sores display the kwashiorkor-like type of malnutrition, a condition characterized by hypoalbuminemic edema, anergy, and decreased peripheral total lymphocyte blood counts ${ }^{16}$.

Based on BMI criterion, most of our malnutrition cases could be classified as marasmus, a fairly well-adapted form of starvation resulting from prolonged energy deficiency, and charac- terized by immunocompetence and relative wound healing preservation. These findings could explain, at least partially, why cases classified as malnourished did not show higher PS frequency. However, marasmic patients are under increased risk of kwashiorkor development because the PS concomitance is associated with local circulatory failure causing capillary thrombosis, tissue hypoxia, and necrosis ${ }^{3}$. In this setting, activated mononuclear cells bring about elevated production of cytokines; and high cortisol levels elicit proteolysis and hypercatabolism, aggravating hypoalbuminemia, and water retention. In this kwashiorkorlike malnutrition ${ }^{4}$ condition, fibroblastic dysfunction may occur, decreasing ulcer healing capacity.

Limitations of this retrospective study include lack of detailed information about nutritional status, including recent weight loss history, food intake recall, and serum albumin levels. In addition, despite the exclusion of cases with manifest body water retention, positive water balance is not rare in acute phase response syndrome patients ${ }^{7}$, and could have had some influence on body weight and body mass index. However, the strict criteria used, which homogeneously distributes eventual errors among groups, and the similar percentage of acute phase response syndrome in both groups, corroborate the present findings. However, prospective studies should be performed to assess the nutritional status of terminal or preterminal patients with pressure sores.

Pressure sore development is a major iatrogenic illness in health care affecting the immobile patient. Because of the PS presence, terminally ill and dying patients may suffer from pain, disfigurement and immobility, which can worsen their quality of life. Implementation of preventive measures to reduce the incidence of PS should include the use of adequate mattresses and cushioned chairs, changes in the bed position every 2-3 hours, and the maintenance of the patient in a dry environment, in addition to adequate nutrition and wound infection prophylaxis.

\section{ACKNOWLEDGEMENT}

To "CNPq" and "FUNEPU", for partial financial support.
CUNHA DF da e col. - Escaras de decúbito em adultos necropsiados com subnutrição - dados preliminares. Rev. Hosp. Clín. Fac. Med. S. Paulo 55(3); 79-82, 2000.

Escaras de decúbito são comuns em pacientes acamados, idosos e subnutridos e podem ocorrer em pacientes terminais devido à imobilidade, incontinência fecal e urinária e imunode- pressão. Além disso, a contaminação das Escaras de decúbito aumentam o risco de sepsis e podem piorar o estado nutricional. O objetivo deste estudo foi comparar a freqüência de Escaras de decúbito entre adultos necropsiados com ou sem subnutrição.

Método: Adultos ( $n=201)$ necropsiados no Hospital Escola da FMTMUberaba entre 1986 e 1996 foram inicialmente incluídos, sendo registrados os dados demográficos e diagnósticos principais, além de peso e altura corporais. Foram excluídos os casos $(n=96)$ com edema (insuficiência cardíaca ou hepática, síndrome nefrótica) e com úlceras de origem vascular. $\mathrm{O}$ indice de massa corporal (IMC $=\mathrm{kg}$ / $\mathrm{m}^{2}$ ) foi utilizado para alocação dos casos em subnutridos (IMC $<18,5 \mathrm{~kg} / \mathrm{m}^{2}$ ) e não-subnutridos (IMC $\geq 18,5 \mathrm{~kg} / \mathrm{m}^{2}$ ).

Resultados: Exceto pelo peso cor- 
poral (42,5; variação: $28-57$ vs 60; 36$134,5 \mathrm{~kg})$ e IMC (16,9; variação: $12,4-$ 18,5 vs 22,7 ; variação: $\left.18,5-54, \mathrm{~kg} / \mathrm{m}^{2}\right)$, respectivamente, não houve diferença estatística entre subnutridos $(n=43)$ e não-subnutridos $(\mathrm{n}=62)$ em relação à idade $(54,9 \pm 20,4$ vs $52,9 \pm 17,9$ anos), percentagem de pessoas brancas $(74,4$ vs $64,5 \%)$, do sexo masculino (76,7 vs $69,3 \%)$ e diagnósticos principais. Escaras de decúbito ocorreram em freqüência similar entre subnutridos $(11,6 \%)$ e não-subnutridos $(11,5 \%)$.

Conclusão: Escaras de decúbito foram igualmente comuns em adultos necropsiados com ou sem subnutrição energética crônica, conforme estimada pelo índice de massa corporal.

DESCRITORES: Escaras de decúbito. Subnutrição protéicoenergética. Necropsias.

Pacientes terminais. Síndrome da resposta de fase aguda.

\section{REFERENCES}

1. ALLMAN RM - Pressure ulcers among the elderly. N Engl J Med 1989; 320:850-853.

2. ALLMAN RM et al. - Pressure ulcer risk factors among hospitalized patients with activity limitation. JAMA $1995 ; \mathbf{2 7 3}: 865-870$.

3. BLISS M \& SIMINI B - When are the seeds of postoperative pressure sores sown? BMJ 1999; 319:863-864.

4. BONNNEFOY $\mathrm{M}$ et al. - Implication of cytokines in the aggravation of malnutrition and hypercatabolism in elderly patients with severe pressure sores. Age Ageing, 1995; 24:37-42.

5. BRESLOW RA \& BERGSTROM N - Nutritional prediction of pressure ulcers. J Am Diet Assoc 1994; 94:1301-1304.

6. CUNHA DF et al. - Reação de fase aguda e parasitismo na veia central da supra-renal de chagásicos crônicos. Rev Soc Bras Med Trop 1994; $27: 83-86$.

7. CUNHA DF et al. - Hyponatremia in acute-phase response syndrome patients in general surgical wards. Am J Nephrol 2000; 20:37-41.

8. ECKMAN KL - The prevalence of dermal ulcers among persons in the U.S. who have died. Decubitus 1989; 2:36-40.

9. EVANS JM et al. - Pressure ulcers: prevention and management. Mayo Clin Proc 1995; 70:789-799.

10. FINUCANE TE - Malnutrition, tube feeding and pressure sores: data are incomplete. J Am Geriatr Soc 1995; 43:447-451.
11. GILMORE SA et al. - Clinical indicators associated with unintentional weight loss and pressure ulcers in elderly residents of nursing facilities. J Am Diet Assoc 1995; 95:984-992.

12. JAMES WP et al. - Definition of chronic energy deficiency in adults. Report of a working party of the International Dietary Energy Consultative Group. Eur J Clin Nutr 1988; 42:969-981.

13. LEVINE JM \& TOTOLOS E - Pressure ulcers: a strategic plan to prevent and heal them. Geriatrics 1995; 50:32-37.

14. LIU MH et al. - Increased energy needs in patients with quadriplegia and pressure ulcers. Adv Wound Care 1996; 9,41-45.

15. OOT-GIROMINI BA - Pressure ulcer prevalence, incidence and associated risk factors in the community. Decubitus 1993; 6:24-32.

16. PINCHCOFSKY-DEVIN GD \& KAMINSKI MV - Correlation of pressure sores and nutritional status. J Am Geriatr Soc 1986; 34:435-440.

17. SHEA JO - Pressure sores: classification and management. Clin Orthop 1975; 112:89-100.

18. SPECTOR WD - Correlates of pressure sores in nursing homes: evidence from the National Medical Expenditure Survey. J Invest Dermatol 1994; 102:42S-45S.

Received for publication on the: $24 / 04 / 00$ 